\title{
Some Concerns for Fire Protection Regulations in Asia and Japanese Way
}

\author{
Kyoichi Kobayashi \\ Center for Fire Science and Technology, Tokyo University of Science, Japan
}

Hello everyone I am Kobayashi of the Tokyo University of Science. Today I would like to talk about the fire protection regulations in Asia and there are several issues concerning this, the fire protection regulations in Asia and I would like to talk about the Japanese approach. (Figure 3-1-1)

We have three major subjects I am going to talk about. (Figure 3-1-2) The first one is the building code and the fire code in Japan.

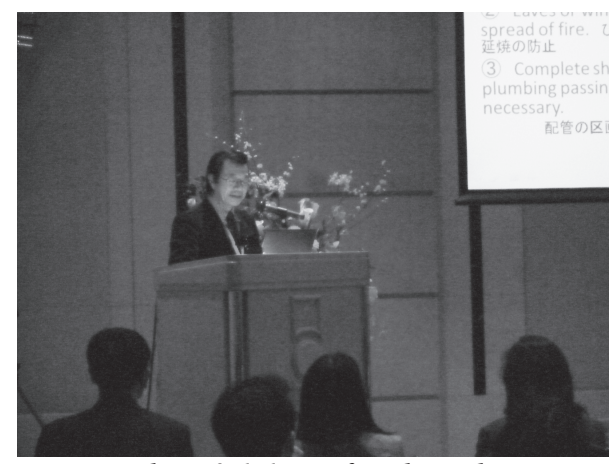

Photo 3-1-1 Prof. Kobayashi

The characteristics or positioning of the Japanese law. Number 2, fire problems in high rise problems. Number 3 , how to ensure fire safety measures during design phase, construction phase, and the maintenance phase and I would like to talk about the Japanese way.

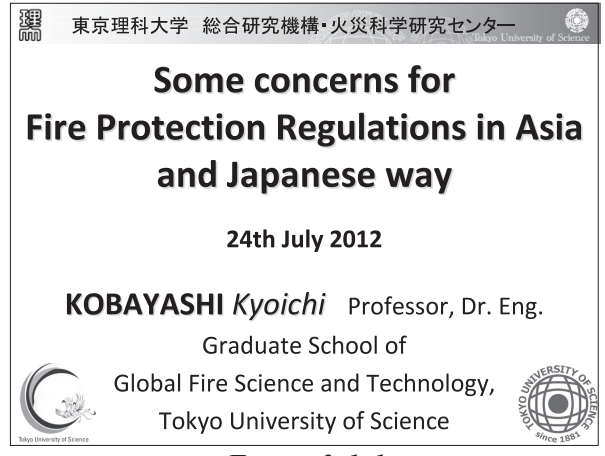

Figure 3-1-1

\section{Subject}

1. Building code and Fire code in Japan 日本の建築基準法と消防法の位置づけ、特徵等

2. Fire problems in High Rise Buildings 高層建築物の火災対策に関する日本の防火法制の特徵

3. How to ensure fire safety measures during design phase, construction phase and maintenance phase 防火対策に関する設計意図を、施工段階、使用段階で反映し ていくための日本の方策

Figure 3-1-2

First of all let me talk about the building code and the fire code in Japan. (Figure 3-1-3)

This is the Japanese administrative system (Figure 3-1-4) of Japan and in which you can find out 11 ministries and also the fire and disaster management agency of the Ministry of General Affairs is responsible for this Fire Service Law. And housing bureau of the Ministry of Land, Infrastructure, Transport and Tourism is responsible for the Building Standard Law. The Building Standard Law covers about the regulations of construction and fire protection. And the Fire Services Law will cover about the fire extinguishing equipment or the fire safety management in both the hardware and software. 


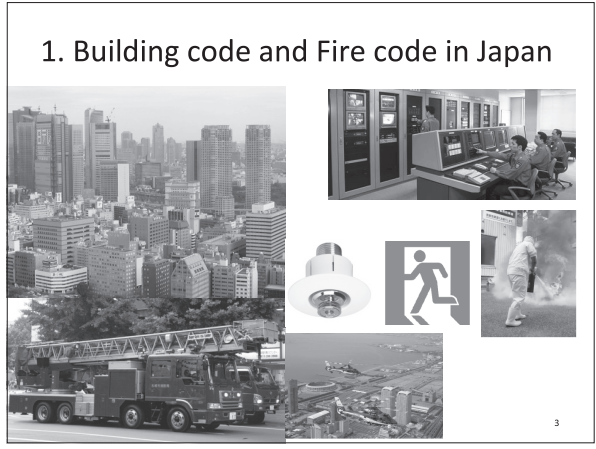

Figure 3-1-3

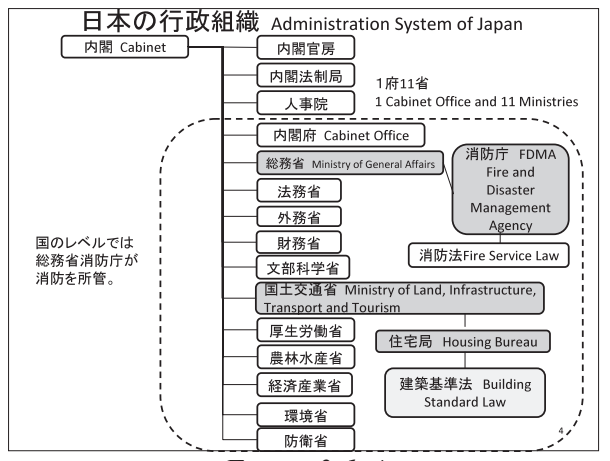

Figure 3-1-4

I just mentioned principles of fire regulation in Japan. (Figure 3-1-5) They have done several principles. Let me introduce just a two of them. First one is that one of the principles of the Japanese regulations is that the multiple standard according to the fire developments, the other thing is that there are lot of potential fire risk of buildings and that they are all going to be flexible enough to make the counter measures, based on the degree of the potential fire risk. So that we

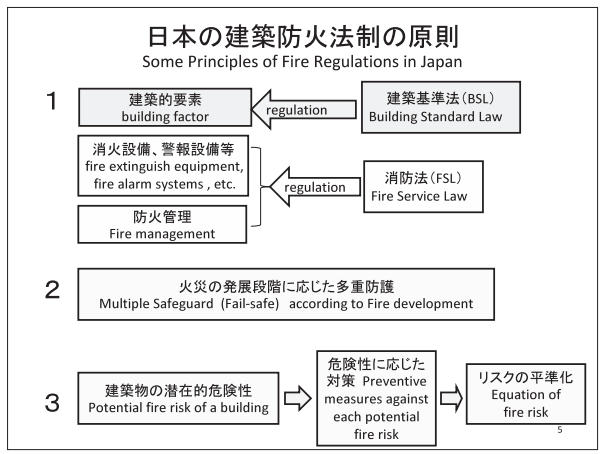

Figure 3-1-5 can have the equation of the fire risk.

This is what kind of counter measure is taken (Figure 3-1-6) according to that development of the fire. I will start from with the ignition source and there would be a set fire and clothes and papers. Also the fire expanded to the furniture and the curtains, the walls and the ceiling, and then it will be into one room. Then it will go into the other buildings and they sometimes will be extended to all the city areas. This is that, the course, the process of development of fires, so based on

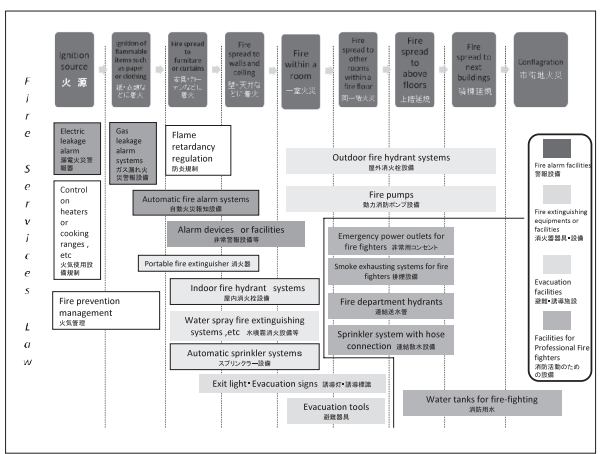

Figure 3-1-6 these different phase of the development.

On the other hand what happens with the Building standard law (Figure 3-1-7).

When we look at all these regulations and one of the other uniqueness in Japan is conflagration (Figure 3-1-8). It has been one of the focus of the fire safety policy in Japan. This is the charts, is a number of this conflagration. A big fire is more than 33000 square 
meters except factory fires and when I look at this, this is the total number, so that for all that the Japan have a decline and a decrease in the number of this conflagrations with the older regulations and actual practice of fire safety practice. Most have been eliminated like this.
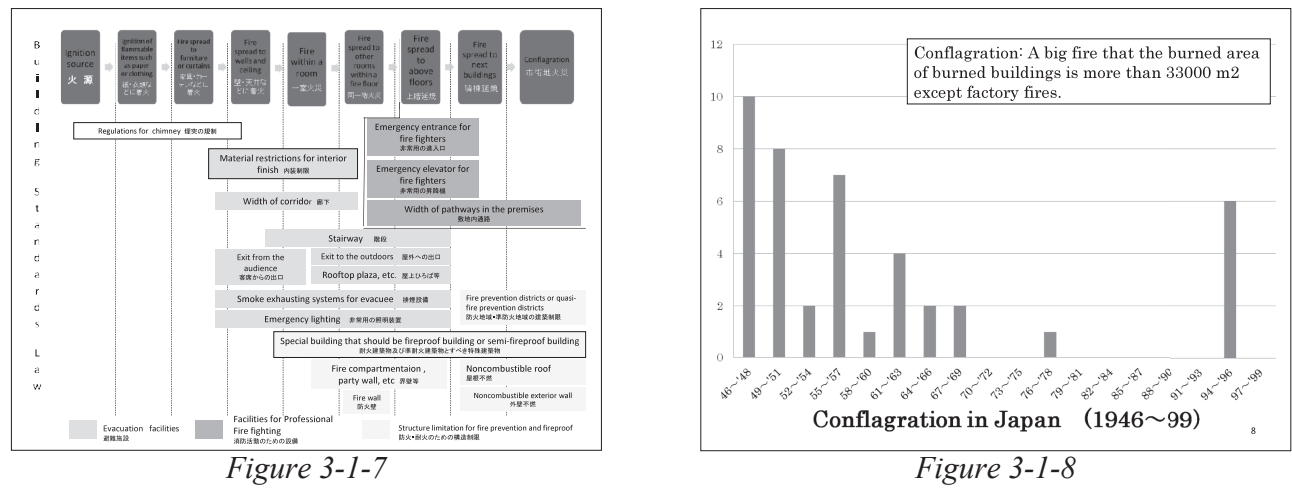

I also studied same cases in Asia like Bangladesh and Philippines and surrounding countries and particularly in the slums, 200 to 300 buildings and households are burnt down but it was the situation we have eliminated 30 years ago in Japan. But would you please look at this in 1995 . This spike was we have the six conflagration caused by the great Hanshin earthquake in 1995.

While we have taken counter measures against wooden building and apartments. In the case of earthquake, situation is different and we have this spike in the Hanshin earthquake and this is the fires of Yamada-cho in the Iwate prefecture caused by tsunami after the great east Japan earthquake on March 11th. (Figure 3-1-9)

A lot of the floating, debris were left over by the tsunami and well, (Figure 3-1-10) that's the debris at fire. Also that the fire brigade cannot get closer to this, the fire. These are two areas and finally this fire get largest together and it was a burnt down about a 15 hectare.

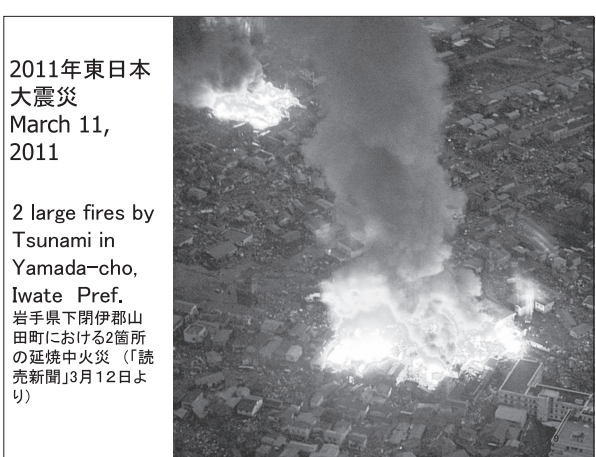

Figure 3-1-9

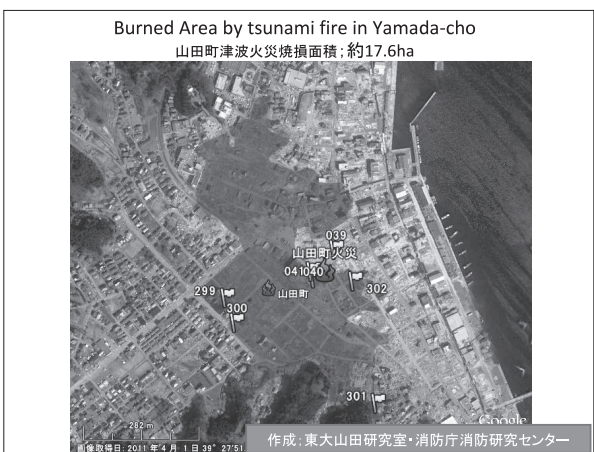

Figure 3-1-10 
This is not only for the Yamada-cho but also for the Miyako or the Ozuchi or Ishinomaki or that. (Figure 3-1-11) When you look at this seven, big fires more than one hectare burnt down.

A lot of wooden apartments and wooden buildings ware fired. We have a large damage burnt down in only one single day.

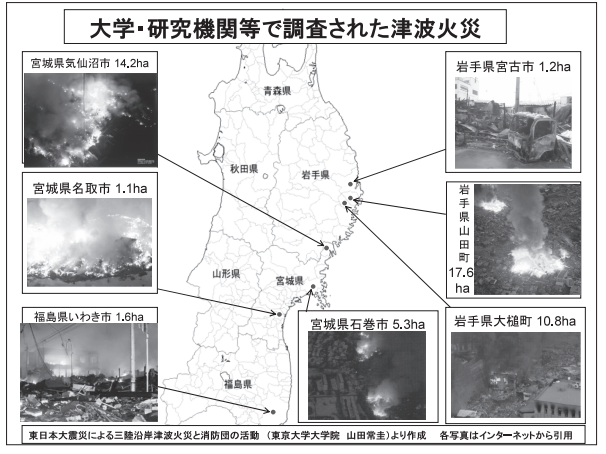

Figure 3-1-11

Next, let me talk about the preventive measures against each potential fire risk level. (Figure 3-1-12) First of all what we can judge the potential risk and we use that as the mark as a use, total floor space, the height of total stories, underground floor or not or high floor or not and also dimension of the windows. These are all used as the criteria for measuring the potential fire accident.

Now the higher and the wider than higher
危険性に応じた対策

Preventive measures against each potential fire risk

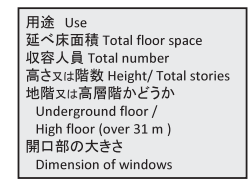

Indicator for potential fire risk of a building

$\bigsqcup^{\circ}$

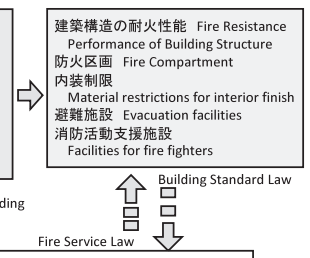

設置すべき消防用設備等 What kind of fire equipment should be placed? Automatic sprinkler systems ?, Automatic fire alarm systems ? ... 防火管理の必要性 Fire manager?, Self fire fighters ?

防炎規制 Flame Retardancy Regulation

Figure 3-1-12

the risk we have. So just like this, based on this ideas and for example, fire service law stipulates that the essential equipment to be installed in the organizations and the systems. But on the other hand, right hand side you can get that bookmarks used for the building standard law. Just like this the fire resistance, performance of building structure or that evacuation facilities, material inflictions for interior finish or the facilities for fire fighters, just like this.

The more dangerous and the more that they are going to get ready and be prepared and installed. These are two different laws, the fire service laws and the building standards law and both try to deal with the prevention of fires like this.

Then this is the fire deaths per 100 fires. From 1968 to 1970 for 100 fires, 10 average fire deaths we had, but now, it only reduced to only one or two with the fire deaths for 100 fires. (Figure 3-1-13)

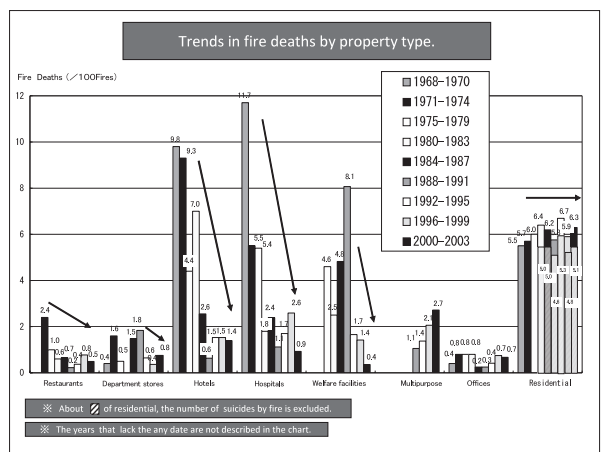

Figure 3-1-13 
Next to hotels you can look at hospitals and now it reduced from 11.7 to 0.9 . This is welfare facilities and elderly care facilities and all the training required is same and for all these the fire deaths per 100 fires have decreased dramatically. On the other hand if you look at the restaurants, the department store and the offices and this, for every fire there is not that high but now it would be about the 0.5 or 0.4 just like this for this commercial facilities and offices.

At that time private residence was safer than the hotels or the hospitals, but now private residence is more dangerous and risky than all these facilities. So that we need to take further countermeasures also for the private residences as in the Professor Sekizawa had mentioned earlier.

We need to first take these statistics and analyze and take countermeasures. These are the essential steps. (Figure 3-1-14) This is different from the chart we have distributed to and what this graph has indicated is that in the more than 30 years ago or 40 years ago we have a lot of advances. Particularly in hotels or hospitals they are obliged to install fire alarms in older buildings and as a result of that, they have been effective and the actual number of fire deaths decreased like

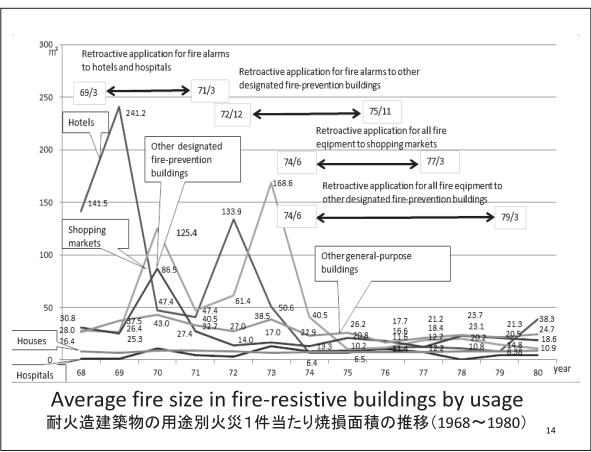

Figure 3-1-14 this.

You can check out the effectiveness of the counter measures to be taken like this. All these statistics and the actual damages would be lowered like this. And so you can clearly understand that this had been very effective in Japan.

What's been increasing in Asian cities is that the high-rise buildings. So let me talk about high-rise buildings. (Figure 3-1-15)

This is about the total number of high-

2. Fire problems in High Rise Buildings rise buildings in Japan which is more than 100 meters in Tokyo and here in Japan the definition of high-rise building is higher than 31 meters. (Figure 3-1-16, 3-1-17)

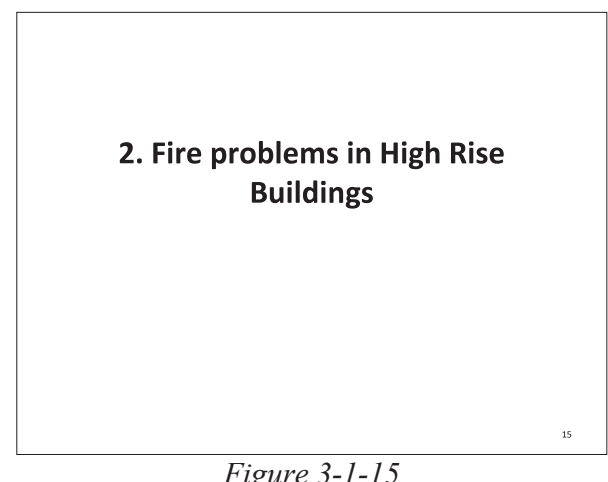

Figure 3-1-15 


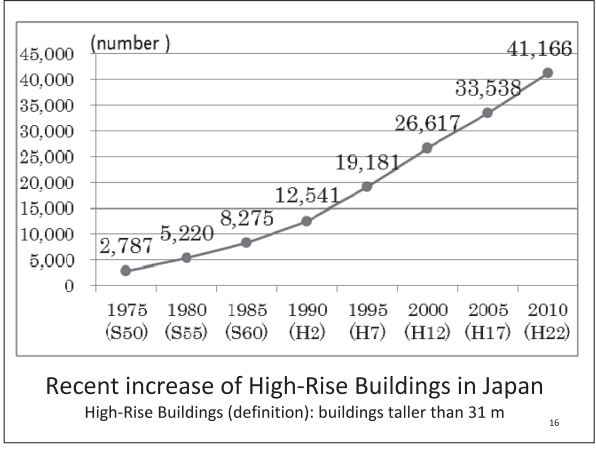

Figure 3-1-16

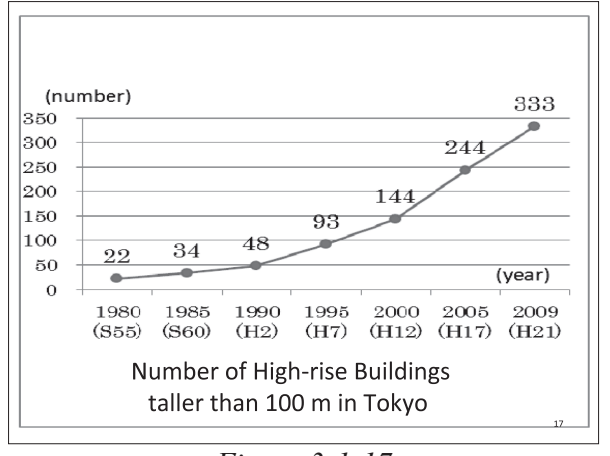

Figure 3-1-17

It comes to the potential risk of fires in highrise. In 40 or 50 years ago, All buildings ware restricted legally - below 31 meters. (Figure 3-1-18) Actually then the maximum height reachable by the ladder was up to 31 meters. So there are some floors in high-rises where that it's not possible to reach with the ladder truck.

As long as ladder truck can be utilized fire brigades can be operating in a platform.

What is the risk of high rise buildings ? 高層建築物の火災危険

- "High Rise Building" in Japan means a building taller than $31 \mathrm{~m}$. 日本の「高層建築物」の定義 : 高さ $31 \mathrm{~m}$ 超

$\rightarrow$ High-rise buildings have floors higher than the fire ladder can reach.

「高層建築物」には、消防車のはしごが届かない階がある

If fire ladders reach the fire floor, fire-fighters can do their work and rescue from a safe place, outside of the burning building.はしごが届けば、消防隊は火災ビルの外側の安 全な場所を拠点として消防活動できる

If the fire ladder can't reach, fire-fighters can't avoid entering the dangerous area of the building to fight.

はしごが届かなければ、消防隊は危険な火災ビルに入って 活動せざるを得ない

、 日本の防火法令はこの認識を元に組み立てられている

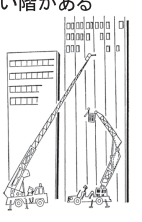

Figure 3-1-18

However, if it's not accessible there might be a danger of the fire fighters to be getting on the very precarious places to provide services.

These are counter measures for such highrises in fire prevention. (Figure 3-1-19) One is that we need to protect the occupants from fire and smoke. We need to provide right evacuation facilities and there should be right firefighting activities and there should be prevention of the building collapse.

For the protection from fire and smoke, the fire brigades find it very difficult to operate if they cannot use the ladder trucks.

\section{Measures that should be taken in high rise buildings 高層ビルの火災対策}

- The following points should be considered in high-rise buildings to deal with the risks mentioned as above.

高層ビルの火災危険に対処するために留意すべきこと

(1) Protection from fire and smoke 火煙からの防御

(2) Evacuation facilities 避難設備

(3) Fire-fighting 消防活動

(4) Protection from collapse 崩壊防止

Figure 3-1-19

The automatic sprinkler system is now the mandated for all old buildings. (Figure 3-1-21) In Japan all high-rise buildings except apartment houses are required to install high sprinkler systems. 


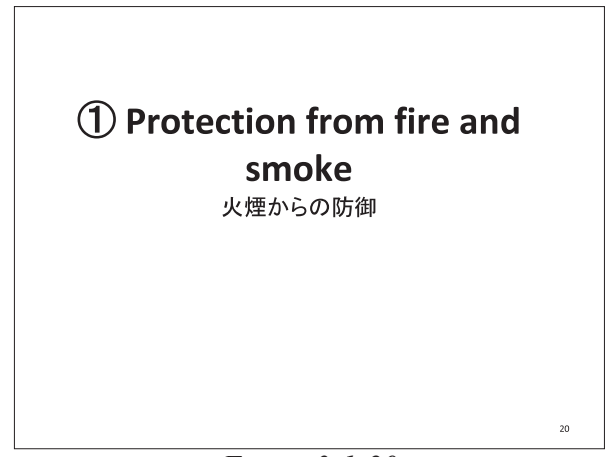

Figure 3-1-20

\section{1-1 Measures for early extinction 初期消火対策}

$\rightarrow$ FSL:

Automatic Sprinkler systems (all high rise buildings must be equipped with sprinkler systems)

日本では消防法により、全ての高層建築物にスプ リンクラー設備の設置を義務づけ

Installation of sprinkler systems is very important in high-rise buildings, because fire-fighter's

performance is relatively limited compared to their performance in normal buildings.

消防活動が制約される高層ビルでは、スプリンクラ一設備は必須

Figure 3-1-21

Also if there is a failure in initial extension there should be prevention of the flashovers effectively. (Figure 3-1-22) According to the Buildings Standards Law there is a limitation for what kind of material is used for the interiors of ceilings and walls.

Those are very important restrictions in Japan. For some other Asian countries according to the building standards law there is not so much regulation to the interior materials. Perhaps there is not so much need to make such restriction because most of the buildings including the ceilings are using the nonflammable materials. But somehow in Japan they wouldn't or some flammable materials were utilized for certain wooden buildings. Unless there is a restriction for such usage there could be a danger of the fire spread.

This is a unique situation in Japan and also according to Japanese Building Standards Law there should be fire compartmentation from 100 square meters up to 1000 square meters and so there should be such a compartmentation and also there should be installment of the smoke control systems. (Figure 3-1-23) Once again that there is a strict regulation what kind of materials are utilized for ceilings and walls.
1.2 Measures for delaying the fire spread 火災拡大の遅延対策

In case early extinction was unsuccessful, the chances of occurring flashover should be reduced, or at least occurrence of flashover should be delayed. 初期消火に失 敗した場合には、フラッシュオーバーを防ぎ、又は遅らせることが必要。

$\rightarrow$ BSL 建築基準法:

- Restriction of using flammable materials for ceilings and walls 天井と床の内装制限

-Smoke control systems

排煙設備の設置

Figure 3-1-22

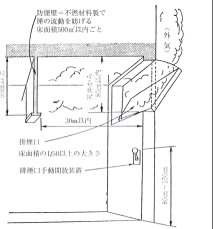


In order to prevent fire to be spreading to the upper floors there is a concept of fire compartment for the vertical space like atrium, staircases and elevator or escalators. (Figure 3-1-24) There is a strict compartmentation system as a fire control. That's from the Building Standards Law.

Also there is eaves and windless wall, which can be effectively utilized for protection of fire spread. There should be a shielding of the gaps. So those are the measures to prevent the fire from spreading to the upper floors. That's the strategy behind this Building Standards Law.

This is about evacuation facilities. (Figure 3-1-25) The staircases leading to upper floors than 15th floor should be equipped with buffer rooms and vestibules. The capacity of the floor spaces for the vestibules and the buffer rooms and special evacuation rooms should be minimum $3 \%$ or higher.

Also this is evacuation staircases and buffer room. (Figure 3-1-26) This is the buffer room and combined the floor area of this staircase and buffer room shall be minimum $3 \%$ or for certain buildings $8 \%$. In this compartmentation should be strengthened as its function. That's one feature to this role, stipulation.

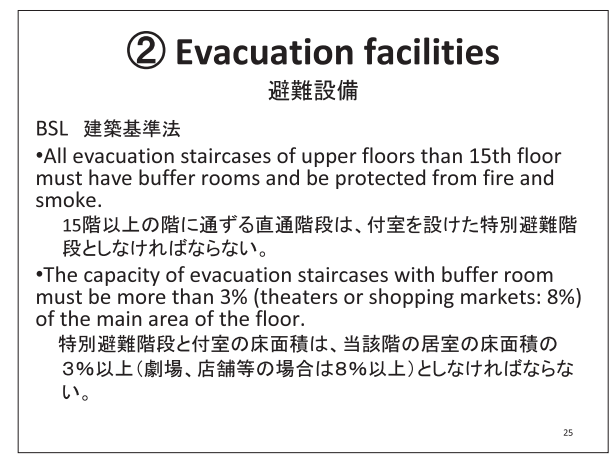

Figure 3-1-25

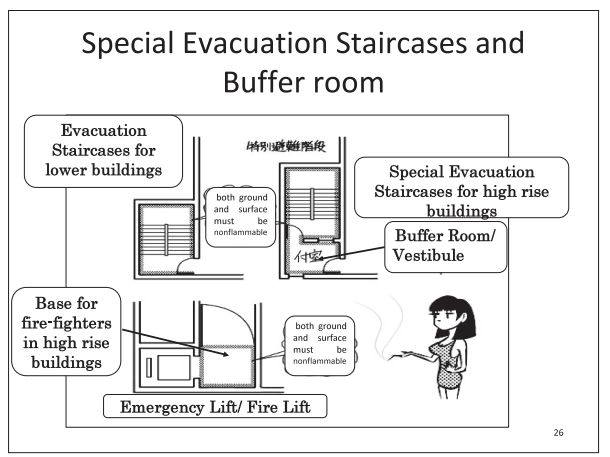

Figure 3-1-26

Next is fire fighters' activities. (Figure 3-1-27)

There should be installation of the evacuation of firefighting use elevators and these are the specifications for such special elevators for emergency use by the law. (Figure 3-1-28) 


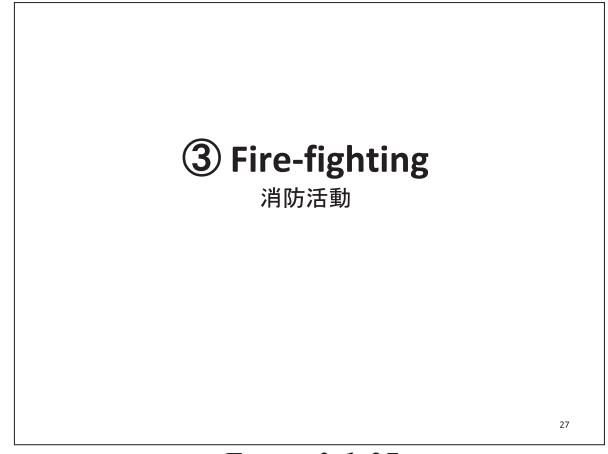

Figure 3-1-27

\subsection{Special elevators dedicated for} fire-fighters must be provided. 消防活動用のエレベーターが必要

$\rightarrow$ BSL : Emergency elevator for fire-fighters

建築基準法では、11階以上のビルには、以下のような仕様 の消防隊が用いる非常用エレベーターの設置を義務づけて いる

- One elevator per floor area of $3000 \mathrm{~m}^{2}$

-The elevator is capable of calling back to the ground floor at command center of the building.

-The elevator has a telephone connected to the command center.

-The elevator is controllable by fire-fighters to keep the door opened.

- The elevator has an emergency battery.

-The elevator runs faster than $60 \mathrm{~m} / \mathrm{min}$.

Figure 3-1-28

Platform for fighters to provide services is important. These lobbies mainly are installed on the buffer room of the special evacuation stairs. (Figure 3-1-29)

Here is more detailed information on fire fighters basis. (Figure 3-1-30) Both stipulated by the Building Standards Law and Fire Services Law.

\subsection{Potential fire-fighters' bases should be placed in each floor. 各階ごとに消防隊の活動拠点が必要 \\ $\rightarrow$ BSL建築基準法: \\ -Emergency elevator lobby of each floor must be capable of being used as fire-fighters' bases. \\ 非常用エレベ一タ一の乗降ロビ一は消防隊の活動拠点と位 \\ 置づけられている \\ - Usually these elevator lobbies are designed in above mentioned buffer rooms. \\ 通常、この乗降ロビーは、特別避難階段の付室に設けられる}

3.3 Fire-fighters' bases should have the following functions and capabilities:消防活動拠点に必要な性能と機能 建築基準法と消防法により、消防活動拠点に必要な性能と機能が 下記のように定められている。

$\rightarrow$ BSL:

-It is safe from fire and smoke (for example, balcony, a room with open windows or equipped with smoke control systems) - It is connected directly to the emergency elevator and/or safe staircase.

-It has provision of enough light in case of power failure.

$\rightarrow$ FSL:

- Fire-fighters must easily contact with headquarters from the base. $\rightarrow$ BSL, FSL:

- Fire-fighters at the base can obtain supply of water, electricity, air cylinders and other fire-fighting tools and equipment. $\rightarrow$ BSL:

-Floor area of the base must be larger than $10 \mathrm{~m}^{2}$ per elevator. ${ }^{30}$ Figure 3-1-30

The most important measures for high rise building fire 高層ビル火災刘策で最も重要なこと building fire is to localize the fire source into that place that fire should be never spread to other floors. (Figure 3-1-31) This is the focus of countermeasures against high-rise building fire. Because if there is a fire spread to the upper floors it takes a longer time for the fire fighters to quell the fire and also there is the danger of the building collapse.
- Fire and smoke should be kept within the fire floor. 火煙を火災階に局限すること

- Because if the fire or smoke spreads above the fire floor in a high-rise building:高層ビル火災で火煙が上階に拡大すると

(1) Fire-fighters cannot do effective fire-fighting and rescue activity on the floors above the fire floor. 火災階の上階で有効な消防活動が出来ない

(2) Fire-fighters have to extinguish by one floor after another 消防隊は、火災階から順に1階ずつ消火せざるを得ない

(?) If fire or smoke spreads through several floors during firefighting, it may take so long a time that the fire building would collapse. 上階延焼すると消火までに長時間を要し、崩壞 の危険
31

Figure 3-1-31 
That's it from me. (Figure 3-1-32)

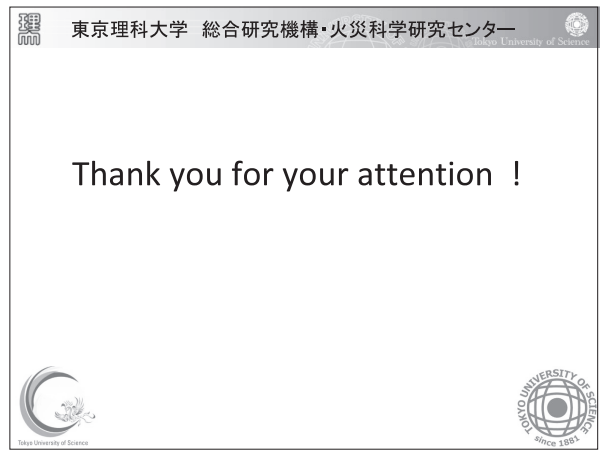

Figure 3-1-32 